\title{
Healthcare Workers' Burdens During the COVID-19 Pandemic: A Qualitative Systematic Review
}

\author{
Apinya Koontalay (D) \\ Wanich Suksatan (1D) ${ }^{2,3}$ \\ Kantapong Prabsangob ${ }^{4}$ \\ Jonaid M Sadang ${ }^{5}$
}

'Faculty of Health, Deakin University, Melbourne, VIC, Australia; ${ }^{2}$ Faculty of Nursing, HRH Princess Chulabhorn College of Medical Science, Chulabhorn Royal Academy, Bangkok, Thailand; ${ }^{3}$ Trudy Busch-Valentine School of Nursing, Saint Louis University, St. Louis, MO, USA; ${ }^{4}$ College of Allied Health Sciences, Suan Sunandha Rajabhat University, Samut Songkram, Thailand; ${ }^{5}$ College of Health Sciences, Mindanao State University, Marawi, Philippines
Correspondence: Wanich Suksatan Faculty of Nursing, HRH Princess Chulabhorn College of Medical Science, Chulabhorn Royal Academy, Bangkok, Thailand

Tel +668-27550027

Email wanich.suk@pccms.ac.th

Kantapong Prabsangob

College of Allied Health Sciences, Suan

Sunandha Rajabhat University, Samut

Songkram, Thailand

$\mathrm{Tel}+66840412068$

Email kantapong.pr@ssru.ac.th
Background: The global healthcare system is continuing to confront major challenges during the current COVID-19 pandemic, with the second wave the deadliest one to date. This study aimed to identify and explore the challenges and burdens of frontline healthcare workers during the current pandemic, and to help prepare workforce support plans for them now and in the future.

Methods: A qualitative systematic review method involving thematic synthesis without meta-analysis was used to analyze relevant studies from five databases from November 2020 to February 2021: MEDLINE via PubMed, CINAHL Complete, Embase through Ovid, Scopus, and Web of Science. The quality of the studies was evaluated using the Critical Appraisal Skills Program Qualitative Research Checklist appraisal tools. This systematic review was conducted in accordance with the PRISMA statement. The informants are healthcare workers working at the frontlines and providing care to COVID-19 patients.

Results: Ten studies revealed the burden of healthcare providers during the COVID-19 pandemic, with having the related challenges experienced by 498 participants (doctors, nurses, pediatric nurses, paramedical staff, support staff, and physiotherapists). Our findings fell into four main themes as follows: inadequate preparedness; emotional challenges; insufficient equipment and information; and work burnout.

Conclusion: The study results demonstrate that the COVID-19 pandemic has had an impact on all aspects of life, especially for healthcare providers, who work on the frontlines. The pandemic has affected the frontline workers' physical and psychological health, causing them to experience emotional distress such as fear, anxiety, depression, and stress. In addition, the pandemic can increase posttraumatic stress disorder, leading to burnout and discontinuity of healthcare workloads to ensure the patients' safety and the high quality of care provided to the patients.

Keywords: COVID-19, healthcare personnel, qualitative studies, qualitative review, qualitative systematic review

\section{Introduction}

Healthcare providers are the frontline soldiers battling against the coronavirus disease 2019 (COVID-19) pandemic. The said pandemic is showing no signs of coming to an end, with a second wave of infections recorded worldwide to date. Most of the new cases spread rapidly through diverse communities. ${ }^{1-4}$ Worldometer $^{5}$ reported that as of October 3, 2021, the total prevalence of global cases is 235 million and there have been 4.81 million deaths. As mentioned earlier, the healthcare providers, who are working as the frontliners during the pandemic, 
are perceived to be overwhelmed and experiencing burnout, even posttraumatic stress disorder (PTSD), from the deluge of COVID-19 cases they have been handling. ${ }^{6,7}$ Sixty percent of healthcare providers such as physicians, nurses, and pharmacists are reported to have experienced burnout. $^{8-13}$ Their heavy workloads affect their ability to cope with the demands of their work and to derive a sense of fulfillment from ensuring patients' safety and providing people with high-quality care. ${ }^{14-17}$

The responsibility of healthcare providers is to directly provide and manage COVID-19 care processes, ${ }^{18,19}$ which, considering the overwhelming number of cases, may cause them to develop mental health issues and fail to perceive their own psychological distress symptoms such as anxiety or depression. ${ }^{20,21}$ The perspectives of healthcare providers experiencing burnout during the current pandemic should thus be obtained to gain a better understanding of how they are handling such situation and to help them resolve their issues. ${ }^{22}$ This study thus systematically reviewed the qualitative researches that have been conducted on healthcare providers' experiences during the current pandemic to synthesize their results and to gain a better understanding of the emotional aspects of workload burden. It also obtained the psychological perspectives of the healthcare providers facing heavy workloads due to the current pandemic situation. The study findings may contribute to the development of a return-to-work readiness program for healthcare providers with PTSD or other mental health issues for after the pandemic, to improve their ability to cope with the demands of their work and to manage their holistic health.

\section{Materials and Methods Study Design}

This systematic qualitative review using the thematic synthesis method was conducted ${ }^{22}$ to analyze the experiences and mental health burdens of healthcare providers during the COVID-19 pandemic.

\section{Search Methods}

The Preferred Reporting Items for Systematic Reviews and Meta-Analyses (PRISMA) statement was used in this review. ${ }^{23}$ Five electronic bibliographic databases were searched: MEDLINE via PubMed, CINAHL (Cumulative Index to Nursing and Allied Health Literature) Complete, Embase through Ovid, Scopus, and Web of Science. The following keywords and
Medical Subject Headings (MeSH) entries were used: healthcare workers, qualitative research, and SARS-CoV -2 or COVID-19. The data were collected from November 1, 2020 to February 1, 2021. The Critical Appraisal Skills Program Qualitative Research Checklist ${ }^{24}$ was used to appraise the quality of the method that was used in each of the selected studies. The critique of the research evidence included an assessment of the quality of the method used by each study. The checklist includes 10 questions for evaluating the study's aims and objectives, the study design, the recruitment strategy used, the data analysis and synthesis, the results and findings, and the overall research value; in sum, the study's quality, integrity, and overall research value. Each question is answerable with "yes," "no," "unclear," or "not applicable," as shown in Table 1. The studies that obtained less than 6 points were excluded. Two researchers independently assessed the eligible articles, and a third researcher conducted quality check and appraisal. Any disagreement or conflict was resolved through a discussion among the researchers.

\section{Inclusion and Exclusion Criteria}

This qualitative systematic review included empirical primary studies with a qualitative research design and published in English that aimed to obtain the perceptions of healthcare providers working with COVID-19 patients. Non-English studies that did not focus on healthcare workers and presented research findings for other pandemic diseases were not included in the review.

\section{Selection and Quality Assessment}

Ninety articles were initially identified in the search. From among these, 13 duplicates were identified through EndNote X9 (Thomson Reuters, PA, USA) and were removed. Sixty-four articles with only the abstract provided were screened by title and abstract to eliminate those among them that were clearly irrelevant to the review, and the 43 full-text articles were screened by title, method, and outcomes for the same purpose. The eligible articles were retrieved and were further discussed. In total, 20 articles were potentially relevant full-text papers, but 10 of these were excluded due to their research design. Finally, only 10 articles met all the inclusion criteria and were thus qualified to be included in the rigorous appraisal (Figure 1). 
Table I The Critical Appraisal Skills Program Qualitative Research Checklist

\begin{tabular}{|c|c|c|c|c|c|c|c|c|c|c|}
\hline \multirow[t]{2}{*}{ Categories } & \multicolumn{10}{|c|}{ Articles } \\
\hline & $A I^{25}$ & $A 2^{26}$ & $A 3^{27}$ & $A 4^{28}$ & $A 5^{29}$ & $A 6^{30}$ & $\mathbf{A} \mathbf{7}^{31}$ & $\mathbf{A} 8^{32}$ & $A 9^{33}$ & $A 10^{34}$ \\
\hline Was there a clear statement of the aims of the research? & $\mathrm{Y}$ & $\mathrm{Y}$ & Y & $\mathrm{Y}$ & $\mathrm{Y}$ & Y & $\mathrm{Y}$ & $\mathrm{Y}$ & Y & $\mathrm{Y}$ \\
\hline Is the qualitative method appropriate? & Y & Y & Y & Y & Y & Y & Y & $Y$ & Y & Y \\
\hline $\begin{array}{l}\text { Was the research design appropriate for addressing the } \\
\text { aims of the research? }\end{array}$ & Y & Y & Y & Y & Y & Y & Y & Y & Y & Y \\
\hline $\begin{array}{l}\text { Was the recruitment strategy appropriate for the aims of } \\
\text { the research? }\end{array}$ & Y & Y & Y & Y & Y & Y & Y & Y & Y & Y \\
\hline $\begin{array}{l}\text { Were the data collected in a way that addressed the } \\
\text { research issue? }\end{array}$ & Y & Y & Y & Y & Y & Y & Y & Y & Y & Y \\
\hline $\begin{array}{l}\text { Was the relationship between the researcher and the } \\
\text { participants adequately considered? }\end{array}$ & Y & $Y$ & Y & Y & Y & Y & Y & Y & Y & Y \\
\hline Were ethical issues taken into consideration? & Y & Y & Y & Y & Y & Y & Y & Y & Y & Y \\
\hline Was the data analysis sufficiently rigorous? & Y & Y & Y & Y & Y & Y & Y & Y & Y & Y \\
\hline Is there a clear statement of the findings? & Y & Y & Y & Y & Y & Y & Y & Y & $Y$ & $Y$ \\
\hline How valuable is the research? & $\mathrm{Y}$ & $\mathrm{Y}$ & Y & $\mathrm{Y}$ & $\mathrm{Y}$ & $\mathrm{Y}$ & Y & $\mathrm{Y}$ & $\mathrm{Y}$ & $\mathrm{Y}$ \\
\hline
\end{tabular}

Abbreviation: Y, “yes”.

\section{Data Extraction}

The following data were extracted from the selected articles: title, year of publication, language published in, country where the study was conducted, study objectives, study method used, sample size, data analysis method used, and findings.

\section{Data Analysis}

A narrative table and summary were prepared by the first author while the second author checked the data accuracy. For data synthesis, the thematic analysis and synthesis method developed by Thomas Harden ${ }^{22}$ was used to categorize the recurring themes in the 10 selected qualitative studies. Thematic synthesis has been found to generate initial codes from the selected articles, describe the themes based on the codes with similar results, and provide basis for deciding on the review and abstract themes, all on the basis of clear qualitative data.

The authors worked independently to review and develop codes, and then each author aggregated the analytical themes twice for each study to double-check the methodical rigor. The primary investigator (PI) and coprimary investigator (co-PI) then reviewed the codes and themes to ensure that these were valid.

\section{Results}

\section{Study Characteristics}

This qualitative systematic review included 10 primary studies with a qualitative design. ${ }^{25-34}$ All the studies were conducted in 2020 in China $(\mathrm{n}=2)$, the United States $(n=2)$, the United Kingdom $(n=2)$, South Korea $(\mathrm{n}=1)$, Brazil $(\mathrm{n}=1)$, Iran $(\mathrm{n}=1)$, and Lebanon $(\mathrm{n}=1)$, and the articles on them were published in the same year. These 10 selected studies had 498 healthcare worker participants, including doctors, nurses, pediatric nurses, paramedics, support staff, and physiotherapists, as summarized in Table 2.

The 10 selected studies were qualitative studies, but one used a mixed-method approach ${ }^{29}$ with appropriate rigor. The data collection methods that were used by the studies consisted of semi-structured, one-to-one, and indepth interviews. Most of the studies conducted the interviews by telephone and through social media, and used thematic and content analyses as data analysis methods.

\section{Main Findings}

The thematic synthesis identified four themes from the data regarding the participants' real experiences in providing care to patients during the COVID-19 pandemic: 


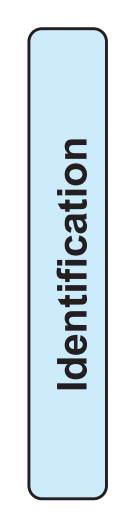

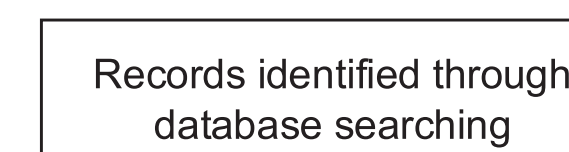

$$
(n=90)
$$

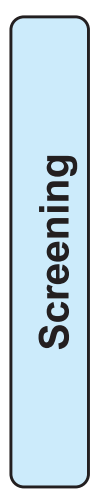

$$
\begin{aligned}
& \text { Records after duplicates removed } \\
& \qquad(\mathrm{n}=3)
\end{aligned}
$$

Additional records identified through other sources

$$
(n=0)
$$
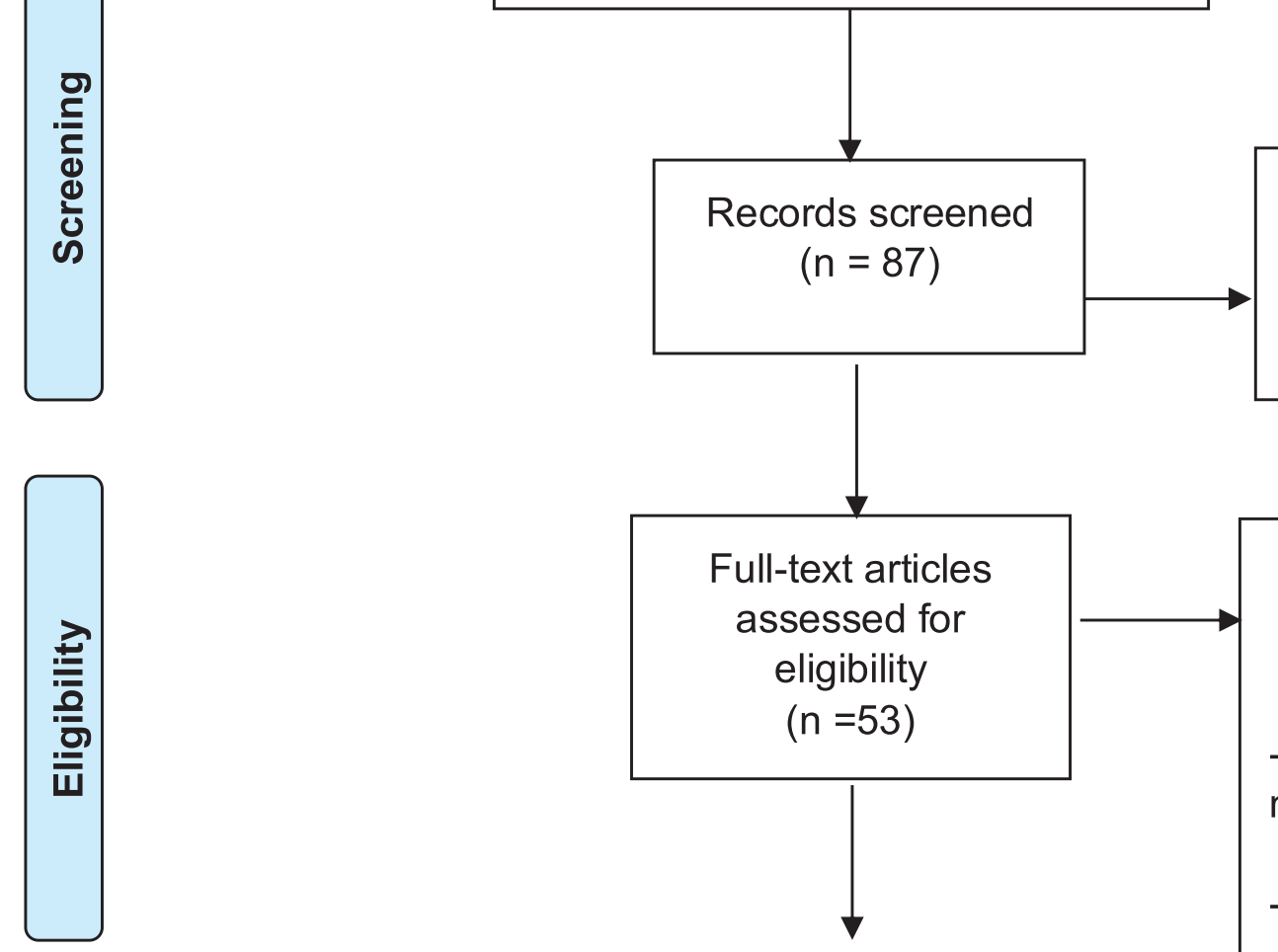

Records excluded on title or abstract $(n=34)$

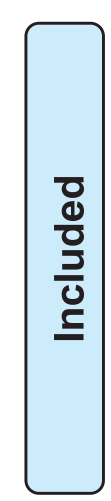

Studies included in final synthesis

$$
(n=10)
$$


Table 2 Summary of Included Studies

\begin{tabular}{|c|c|c|c|c|c|}
\hline $\begin{array}{l}\text { Author } \\
\text { (Year), } \\
\text { Country }\end{array}$ & Study Aim & Target Sample & Study Design & $\begin{array}{c}\text { Data Collection } \\
\text { Method }\end{array}$ & Major Findings \\
\hline 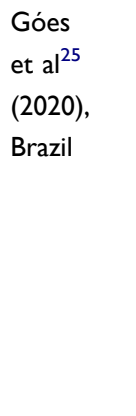 & $\begin{array}{l}\text { To identify the challenges } \\
\text { faced by pediatric nurses in } \\
\text { relation to the COVID-19 } \\
\text { pandemic }\end{array}$ & $\begin{array}{l}\text { Pediatric nurses }(n= \\
26)\end{array}$ & $\begin{array}{l}\text { Qualitative } \\
\text { approach }\end{array}$ & $\begin{array}{l}\text { Semi-structured } \\
\text { interviews }\end{array}$ & $\begin{array}{l}\text { - Presence of stress from } \\
\text { being frontline workers } \\
\text { Limited time to prepare for } \\
\text { care provision } \\
\text { - Insufficient number of } \\
\text { workers, leading to the } \\
\text { healthcare providers' } \\
\text { exhaustion and burnout } \\
\text { while providing care to } \\
\text { COVID- } 19 \text { patients }\end{array}$ \\
\hline $\begin{array}{l}\text { Fawaz and } \\
\text { Samaha }^{26} \\
(2020) \text {, } \\
\text { Lebanon }\end{array}$ & $\begin{array}{l}\text { To explore the } \\
\text { psychological effects of } \\
\text { being quarantined following } \\
\text { exposure to COVID-19 }\end{array}$ & $\begin{array}{l}\text { Healthcare } \\
\text { professionals }(n= \\
\text { 13) }\end{array}$ & $\begin{array}{l}\text { Qualitative } \\
\text { research }\end{array}$ & $\begin{array}{l}\text { Semi-structured } \\
\text { interviews and } \\
\text { phenomenology analysis }\end{array}$ & $\begin{array}{l}\text { - Presence of psychological } \\
\text { challenges due to } \\
\text { quarantines } \\
\text { - Presence of fear, anger, } \\
\text { being conflicted, } \\
\text { frustration, anxiety } \\
\text { - Conflict between } \\
\text { professional duty and family } \\
\text { obligation } \\
\text { - Stigma } \\
\text { - insufficient equipment and } \\
\text { information }\end{array}$ \\
\hline $\begin{array}{l}\text { Arnetz } \\
\text { et } \mathrm{a}^{27} \\
(2020) \text {, } \\
\text { USA }\end{array}$ & $\begin{array}{l}\text { To explore the US nurses' } \\
\text { perceptions of the most } \\
\text { salient sources of their } \\
\text { stress in the early stages of } \\
\text { the COVID-I } 9 \text { pandemic }\end{array}$ & Nurses $(n=455)$ & $\begin{array}{l}\text { Qualitative } \\
\text { content analysis of } \\
\text { open-ended } \\
\text { questions }\end{array}$ & $\begin{array}{l}\text { - The open-ended } \\
\text { question "What are the } \\
\text { most stressful situations } \\
\text { you have dealt with } \\
\text { during the COVID-I9 } \\
\text { pandemic?" } \\
\text { - Thematic analysis, } \\
\text { providing the } \\
\text { framework of the code } \\
\text { system }\end{array}$ & $\begin{array}{l}\text { - Emotional distress caused } \\
\text { by dealing with many } \\
\text { unknowns during the } \\
\text { pandemic } \\
\text { - Exhaustion with the } \\
\text { pandemic } \\
\text { - Helplessness during the } \\
\text { pandemic } \\
\text { - Lack of trust in the } \\
\text { workplace } \\
\text { - Inadequate protective } \\
\text { equipment (eg, PPEs) }\end{array}$ \\
\hline $\begin{array}{l}\text { Lee and } \\
\text { Lee }^{28} \\
(2020) \\
\text { South } \\
\text { Korea }\end{array}$ & $\begin{array}{l}\text { To explore the experiences } \\
\text { of nurses who provided } \\
\text { care for COVID-19 patients }\end{array}$ & $\begin{array}{l}\text { Hospital nurses }(n= \\
\text { I8) }\end{array}$ & $\begin{array}{l}\text { Qualitative study } \\
\text { of } \\
\text { phenomenological } \\
\text { analysis }\end{array}$ & $\begin{array}{l}\text { In-depth individual } \\
\text { interviews by telephone }\end{array}$ & $\begin{array}{l}\text { - Emotional distress } \\
\text { - Lack of preparation for } \\
\text { providing COVID-19 } \\
\text { patient care } \\
\text { - Unfamiliar work, } \\
\text { challenges posed by having } \\
\text { to wear PPEs, and } \\
\text { unpredictable nature of the } \\
\text { COVID-19 pandemic } \\
\text { - Burnout from heavy } \\
\text { workload } \\
\text { - Need for support from } \\
\text { family and friends }\end{array}$ \\
\hline
\end{tabular}

(Continued) 
Table 2 (Continued).

\begin{tabular}{|c|c|c|c|c|c|}
\hline $\begin{array}{l}\text { Author } \\
\text { (Year), } \\
\text { Country }\end{array}$ & Study Aim & Target Sample & Study Design & $\begin{array}{c}\text { Data Collection } \\
\text { Method }\end{array}$ & Major Findings \\
\hline $\begin{array}{l}\text { George } \\
\text { et } \mathrm{al}^{29} \\
(2020) \text {, } \\
\text { Bangalore }\end{array}$ & $\begin{array}{l}\text { To describe the initial } \\
\text { dilemma and mental stress } \\
\text { experienced by healthcare } \\
\text { providers, and the adaptive } \\
\text { measures taken by them }\end{array}$ & $\begin{array}{l}\text { A healthcare team of } \\
\text { doctors, nurses, and } \\
\text { paramedical and } \\
\text { support staff } \\
(n=42)\end{array}$ & $\begin{array}{l}\text { Mixed-method } \\
\text { study }\end{array}$ & $\begin{array}{l}\text { Qualitative in-depth } \\
\text { interviews }\end{array}$ & $\begin{array}{l}\text { - Emotional distress such as } \\
\text { stress, stigma, fear, guilt, } \\
\text { and isolation } \\
\text { - Exhaustion and burnout } \\
\text { due to heavy workload }\end{array}$ \\
\hline 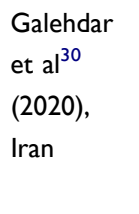 & $\begin{array}{l}\text { To explore nurses' } \\
\text { experiences of } \\
\text { psychological distress while } \\
\text { providing care to COVID- } \\
19 \text { patients }\end{array}$ & Nurses $(n=11)$ & $\begin{array}{l}\text { Qualitative } \\
\text { research }\end{array}$ & $\begin{array}{l}\text { Conventional content } \\
\text { analysis }\end{array}$ & $\begin{array}{l}\text { - High level of psychological } \\
\text { distress } \\
\text { - Negative feeling toward } \\
\text { PPEs }\end{array}$ \\
\hline 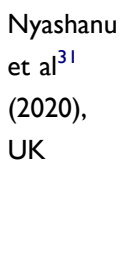 & $\begin{array}{l}\text { To explore the challenges } \\
\text { faced by different frontline } \\
\text { workers in health and social } \\
\text { care during the COVID-19 } \\
\text { pandemic }\end{array}$ & $\begin{array}{l}\text { Healthcare providers } \\
(n=40) \text {, including } \\
\text { nurses }(n=15) \text {, } \\
\text { support workers ( } \\
=15) \text {, and managers } \\
(n=10)\end{array}$ & $\begin{array}{l}\text { Explorative } \\
\text { qualitative } \\
\text { research }\end{array}$ & $\begin{array}{l}\text { In-depth, one-to-one, } \\
\text { semi-structured } \\
\text { interviews }\end{array}$ & $\begin{array}{l}\text { - Inadequate pandemic } \\
\text { preparedness } \\
\text { - Psychological distress } \\
\text { such as anxiety and fear } \\
\text { - Challenges of social } \\
\text { distancing }\end{array}$ \\
\hline $\begin{array}{l}\text { Bennett } \\
\text { et } \mathrm{al}^{32} \\
(2020) \text {, } \\
\text { UK }\end{array}$ & $\begin{array}{l}\text { To gain insights into the } \\
\text { experiences and concerns } \\
\text { of frontline National Health } \\
\text { Service (NHS) workers } \\
\text { while caring for COVID-19 } \\
\text { patients }\end{array}$ & $\begin{array}{l}\text { Community of NHS } \\
\text { workers (doctors, } \\
\text { nurses, and } \\
\text { physiotherapists) } \\
\text { with social media } \\
\text { access ( }=54 \text { ) }\end{array}$ & Qualitative analysis & $\begin{array}{l}\text { Thematic analysis to } \\
\text { identify themes }\end{array}$ & $\begin{array}{l}\text { - Posttraumatic distress } \\
\text { caused by being } \\
\text { overwhelmed with one's } \\
\text { workload } \\
\text { - Feeling of shock from the } \\
\text { rapidly changing nature of } \\
\text { the pandemic } \\
\text { - Healthcare providers' } \\
\text { perception of inequality in } \\
\text { the workplace, leading to } \\
\text { rifts between the senior } \\
\text { manager and the frontline } \\
\text { staff }\end{array}$ \\
\hline 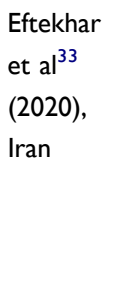 & $\begin{array}{l}\text { To undertake an in-depth } \\
\text { exploration of the } \\
\text { experiences of healthcare } \\
\text { staff working during the } \\
\text { COVID-19 pandemic }\end{array}$ & $\begin{array}{l}\text { Healthcare } \\
\text { professionals }(n= \\
97)\end{array}$ & Qualitative study & $\begin{array}{l}\text { Thematic analysis and } \\
\text { semi-structured } \\
\text { interviews }\end{array}$ & $\begin{array}{l}\text { - Adaptation to the } \\
\text { pandemic era. } \\
\text { - Psychological distress in } \\
\text { the long term, such as } \\
\text { anxiety, fear, depression, } \\
\text { helplessness, hopelessness, } \\
\text { and burnout }\end{array}$ \\
\hline $\begin{array}{l}\text { Liu et } \mathrm{al}^{34} \\
(2020) \text {, } \\
\text { China }\end{array}$ & $\begin{array}{l}\text { To describe the experiences } \\
\text { of physicians and nurses } \\
\text { caring for COVID-19 } \\
\text { patients in the early stages } \\
\text { of the pandemic }\end{array}$ & $\begin{array}{l}\text { Nurses }(n=9) \\
\text { Physicians }(n=4)\end{array}$ & Qualitative study & $\begin{array}{l}\text { - Semi-structured, in- } \\
\text { depth interviews by } \\
\text { telephone } \\
\text { - Data analysis using the } \\
\text { phenomenological } \\
\text { method }\end{array}$ & $\begin{array}{l}\text { - Challenges in providing } \\
\text { care in COVID-19 wards } \\
\text { - Heavy workloads } \\
\text { - Perception of fear caused } \\
\text { by working as a frontliner } \\
\text { in a stressful situation }\end{array}$ \\
\hline
\end{tabular}

Abbreviations: COVID-19, coronavirus disease 2019; PPE, personal protective equipment. 
inadequate preparedness, emotional challenges, insufficient equipment and information, and work burnout, as shown in Table 3.

\section{Discussion}

In this research work, 10 empirical qualitative studies were systematically reviewed to synthesize their findings and to identify how healthcare providers manage their mental health amidst their burdens while working with COVID19 patients. They play crucial roles as frontliners coping with a disease of which little is known and that is thus unpredictable This review addressed the experience and perceptions of the healthcare providers worldwide to gain a better understanding of how they feel while working with serious COVID-19 patients. Altogether, the findings of this research work can help healthcare providers

Table 3 Summary of Thematic Analysis

\begin{tabular}{|c|c|}
\hline Main Themes & Code in the Texts \\
\hline $\begin{array}{l}\text { Inadequate } \\
\text { preparedness }\end{array}$ & $\begin{array}{l}\text { - Frontline work without preparedness }{ }^{28} \\
\text { - Limited pandemic preparedness } s^{31} \\
\text { - Poor coping with rapid changes }{ }^{32}\end{array}$ \\
\hline Emotional challenges & $\begin{array}{l}\text { - Fear of unpredictable enemy }{ }^{28} \\
\text { - Emotional distress due to the fear of } \\
\text { contracting the virus }{ }^{30} \\
\text { - Stigma of contracting the virus }{ }^{29} \\
\text { - Anxiety and fear among frontline } \\
\text { workers } \\
\text { - New experiences of drastic changes } \\
\text { - Negative psychological effects } \\
\text { - Fear of providing COVID- } 19 \text { care }^{27} \\
\text { - Fear of transmitting the virus } \\
\text { - Fear of being in the frontlines }{ }^{25} \\
\text { - Fear of contracting the virus } \\
\text { - Stigma } \\
26,29\end{array}$ \\
\hline $\begin{array}{l}\text { Insufficient equipment } \\
\text { and information }\end{array}$ & $\begin{array}{l}\text { - Lack of standardized guidelines for } \\
\text { COVID-19 prevention and control }{ }^{31} \\
\text { - Inadequate training and information on } \\
\text { new diseases }{ }^{27,29} \\
\text { - Dealing with an unpredictable } \\
\text { pandemic } \\
\text { - Lack of PPEs } \\
26,29\end{array}$ \\
\hline Work burnout & $\begin{array}{l}\text { - Burnout due to being in the frontlines, } \\
\text { fighting against COVID-1928,29,33,34 } \\
\text { - Exhaustion and burnout due to the } \\
\text { widespread COVID- } 19 \text { infection }{ }^{27} \\
\text { - Inequality within the healthcare system } \\
32\end{array}$ \\
\hline
\end{tabular}

Abbreviations: COVID-19, coronavirus disease 2019; PPE, personal protective equipment. manage and improve their mental health status. The study findings offer a deeper understanding of healthcare providers' perceptions of their psychological conditions in four themes: (1) inadequate preparedness; (2) emotional challenges; (3) insufficient equipment and information; and (4) work burnout.

The first theme was inadequate preparedness or being poorly prepared for working during a serious pandemic. Most of the healthcare providers in the reviewed studies stated that they were overwhelmed as they had to work in crisis situations, which affected them physically and emotionally as they had limited time to prepare for the rapid increase of new cases. Lee et al $(2020)^{28}$ explored the experiences of South Korean nurses who were also unprepared to work with COVID-19 patients as they were unfamiliar with the little-known disease. George et al $(2020)^{32}$ conducted a study on Indian healthcare providers working in an urban slum area in the first 40 days of the crisis who had limited preparation for such and who thus developed several mental health problems. Bennett et al $(2020)^{32}$ presented the experiences of the UK frontliners who could hardly cope with the rapid changes occurring during the pandemic, which made them suffer from physical and mental health issues while taking care of COVID-19 patients.

The second theme that was found in the study data was facing the challenges posed by several types of emotional distress that developed during the pandemic, such as fear, $^{29,31}$ stigma, $^{26,29}$ anxiety, $^{31,33}$ and depression. ${ }^{31} 33$ Goes et al $(2020)^{25}$ found that in Brazil, pediatric nurses are suffering from stress as frontline workers, in addition to psychological distress, which may lead to discontinued occupational health and poor quality of care provided. Fawaz and Samaha (2020) ${ }^{26}$ explored the perceptions of Lebanese healthcare professionals who had been quarantined after caring for patients with COVID-19. They had developed psychological distress, such as fear, anger, frustration, and stigma, and they were overwhelmed by the conflicts that they encountered between their professional duties and their duties toward their families. Arnet et al (2020) ${ }^{27}$ surveyed the sources of stress in the US nurses working with COVID-19 patients and found that most of them were overwhelmed by the unpredictability of COVID-19 and were afraid of passing on the virus to their families. Lee et al $(2020)^{28}$ found that South Korean nurses fear and struggle with working as frontliners in the unpredictable pandemic. George et al $(2020)^{29}$ found that the Indian healthcare professionals who worked 
in the frontlines in the first 40 days of the COVID-19 crisis perceived emotional distress such as stress caused by the unpredictable nature of the new virus strains emerging and fear of contracting the COVID-19. Also, they had been stigmatized and felt guilt toward their families and friends, who could contract the virus from them. Galehdar et al $(2020)^{28}$ explored Iranian nurses' experiences of mental distress while working with COVID-19 patients and found that most of them had a high level of psychological distress (eg, anxiety and fear) and stated that they considered working during the COVID-19 pandemic a waste of their time. Nyashanu et al $(2020)^{31}$ conducted a study on the UK frontline workers providing care to COVID-19 patients and found that most of them had anxiety and fear caused by the limited time that they had to prepare for the unpredictable pandemic, and their poor preparation for such as a result. Bennett et al (2020) ${ }^{32}$ stated that the members of the UK National Health Service (doctors, nurses, physiotherapists) are insecure about providing care to COVID-19 patients due to their limited time to prepare for the pandemic and the rapid changes occurring in the disease. Eftekhar et al $(2020)^{33}$ found that the Iranian healthcare providers who are in the frontlines during the COVID-19 pandemic perceive negative emotions in themselves that may affect them in the long term, such as anxiety, depression, fear, hopelessness, and burnout. Consequently, the pandemic is affecting them psychologically, making them feel overwhelmed and causing them to suffer from several emotional problems due to their lack of experience in dealing with the dreaded disease, their lack of pandemic preparedness, and the inadequate control guidelines available to prevent their infection.

The third theme obtained from the study data was the fact that there are insufficient equipment and information about the pandemic. Goes et al $(2020)^{25}$ demonstrated that Brazilian pediatric nurses are facing challenges due to the insufficiency of the available protective equipment (eg, personal protective equipment [PPE]) and of the guidelines for the standard precautions for frontline workers during the pandemic. Similarly, Arnetz et al (2020) ${ }^{27}$ investigated the US nurses' sources of stress and found that these were their lack of trust in workplace safety due to the inadequate protective equipment (eg, PPEs) and the poor preparation of the protocol or guideline for providing care to COVID-19 patients. Also, Nyashanu et al (2020) ${ }^{31}$ found that the UK healthcare workers have inadequate protective equipment such as PPEs.
Finally, the fourth theme obtained from the study data was work burnout. Most of the healthcare providers worldwide are overwhelmed by their workload due to the insufficiency of the healthcare staff on account of the rapid and wide spread of the disease, and perceive inequality within the healthcare system. Arnetz et al $(2020)^{27}$ found that the US nurses were exhausted and felt helpless in the workplace during the early stages of the pandemic as they did not trust the management and as there were inadequate sources of help for them throughout the pandemic thus far. They were also not comfortable donning a PPE while working. Lee et al $(2020)^{28}$ reported that the South Korean nurses' burnout due to the pandemic is affecting them physically and emotionally. That is, they feel exhausted and fear that they will fail to cope with their posttraumatic distress, which directly affects their relationship with their co-workers and patients and the quality of care that they provide. George et al $(2020)^{29}$ reported that Bangalore's healthcare providers working with COVID-19 patients are exhausted and burnt out due to their heavy workload. Bennett et al $(2020)^{32}$ reported that the UK healthcare workers perceive the existence of inequity in the workplace, as shown by the rifts between the senior managers and those who are on the frontlines. Eftekhar et al $(2020)^{33}$ found that the Iranian healthcare providers have difficulty adapting to the pandemic and are largely unsuccessful in coping with their emotional issues, thus experiencing burnout. Liu et al $(2020)^{34}$ found that the nurses and physicians in China are overwhelmed by their heavy workloads and are thus fearful and stressed due to the unpredictable pandemic.

To date, the COVID-19 pandemic has changed the world. Healthcare providers worldwide are unprepared for it and are facing many uncertainties with regard to it. They have been working without proper preparation, training, or standardized guidelines. Consequently, they are unsuccessful in their coping responses due to the insufficiency of the relevant information, equipment, support, and equality of respect to work. Healthcare providers working with COVID-19 patients are overwhelmed and exhausted by their workload burden ${ }^{34}$ and by the uncertainties of the pandemic and have thus come to experience burnout. More than $50 \%$ of the healthcare frontliners are reported to have become burnt out. ${ }^{35-38}$ Additionally, most of them have emotional challenges stemming from their fear of death, guilt for transmitting the virus to their families, and stigma from the community. ${ }^{29}$ Also, they feel depressed due to their multiple duties, their 
challenging new work environments (eg, having to work in a negative room), and their discomfort with their PPEs especially in restricted zones. ${ }^{34}$ Besides, they experience loss of control when carrying out heavy duties, expressing that they work like robots, enjoy their human relationships in the workplace less, and feel sad that they have to avoid touching, hugging, and talking with their co-workers. ${ }^{33}$

In summary, globally, healthcare providers who are on the frontlines of the battle against the COVID-19 pandemic, providing care to COVID-19 patients, are struggling and experiencing burnout, making them frustrated and stressed out due to posttraumatic stress. ${ }^{32}$ This research work focused on how healthcare workers manage to work under stress during the COVID-19 pandemic. On the basis of the study's findings, it is strongly recommended that healthcare providers be equipped with pandemic preparedness to help them cope with the demands of their work before, during, and after the COVID-19 pandemic. Such frontliners may suffer from mental health issues as they have dedicated themselves to providing direct care for their COVID-19 patients and carrying out their duties toward their family at the same time. Pandemic preparedness may prevent symptoms of emotional distress and may promote teamwork in carrying the burdens posed by the pandemic, thus preventing the occurrence of occupational health issues, helping healthcare providers maintain positive relationships in the workplace, and improving the patients' safety and the quality of care provided to the patients.

\section{Conclusion}

Healthcare providers are the ones who are battling against COVID-19 at the frontlines, in the midst of rapidly changing procedures for dealing with the ongoing crisis. They experience challenges in dealing with the unpredictable pandemic due to their limited preparedness, the rapid changes occurring in the disease, and the difficulty of performing their duties due to the lack of protocol, accurate information, and proper equipment for preventing contamination. Limited preparedness may lead to physical and psychological problems such as high levels of stress, anxiety, fear, helplessness, hopelessness, anger, and stigma. However, healthcare providers working with COVID-19 patients endeavor to fulfill their duties professionally and sacrifice as much as they could. On the other hand, their heavy workload may lead to their burnout and to the discontinuity of their healthcare practice, and may threaten the patients' safety. The findings from this research work suggest that a better understanding of healthcare providers' experiences while providing care to COVID-19 patients may help in developing training programs for them and in enabling them to better manage the pandemic. In addition, programs focusing on the PTSD symptoms of healthcare providers can be implemented to help them more effectively cope with the current crisis, improve their mental health during work, and reduce their posttraumatic disorders stemming from the COVID-19 pandemic.

\section{Abbreviations}

COVID-19, CoV, novel coronavirus; coronavirus disease 2019; SARS-CoV, Severe acute respiratory syndrome; MERS-CoV, Middle East Respiratory Syndrome; PRISMA, Preferred reporting items for systematic reviews and meta-analyses; PPE, personal protective equipment, PTSD, posttraumatic stress disorder.

\section{Acknowledgment}

We would like to thank the participants in our work for their valuable data, the reviewers for their helpful comments and suggestions to improve our study. The study was partially funded by the Suan Sunandha Rajabhat University in Bangkok, Thailand.

\section{Disclosure}

The authors of this study declare that they have no conflicts of interest in this project.

\section{References}

1. Bateman ME, Hammer R, Byrne A, et al. Death Cafés for prevention of burnout in intensive care unit employees: study protocol for a randomized controlled trial (STOPTHEBURN). Trials. 2020;21 (1):1019. doi:10.1186/s13063-020-04929-4

2. Suksatan W, Choompunuch B, Koontalay A, Posai V, Abusafia AH. Predictors of Health Behaviors Among Undergraduate Students During the COVID-19 Pandemic: a Cross-Sectional Predictive Study. J Multidiscip Healthc. 2021;14:727-734. doi:10.2147/ JMDH.S306718

3. Choompunuch B, Suksatan W, Sonsroem J, Kutawan S, In-udom A. Stress, adversity quotient, and health behaviors of undergraduate students in a Thai university during COVID-19 outbreak. Belitung Nursing J. 2021;7(1):1-7. doi:10.33546/bnj.1276

4. Posai V, Suksatan W, Choompunuch B, Koontalay A, Ounprasertsuk J, Sadang JM. Assessment of the Health-Promoting Behaviors of Hospitalized Patients with Non-Communicable Diseases During the Second Wave of COVID-19. J Multidiscip Healthc. 2021;14:2185-2194. doi:10.2147/JMDH.S329344

5. Worldometers. COVID-19 Coronavirus pandemic; 2021. https://www. worldometers.info/coronavirus/. Accessed October 3, 2021.

6. Duarte I, Teixeira A, Castro L, et al. Burnout among Portuguese healthcare workers during the COVID-19 pandemic. BMC Public Health. 2020;20(1):1885. doi:10.1186/s12889-020-09980-z 
7. Kaku SM, Moscoso A, Sibeoni J, Sravanti L. Transformative learning in early-career child and adolescent psychiatry in the pandemic. Lancet Psychiatry. 2021;8(2):e5. doi:10.1016/S2215-0366(20) 30524-1

8. Hammer R, Ravindran N, Nielsen N. Can Death Cafés resuscitate morale in hospitals? Med Humanit. 2021;47(1):2. doi:10.1136/medhum-2018-011607

9. Dzau VJ, Kirch DG, Nasca TJ. To care is human-collectively confronting the clinician-burnout crisis. N Engl J Med. 2018;378 (4):312-314. doi:10.1056/NEJMp1715127

10. Moss M, Good VS, Gozal D, Kleinpell R, Sessler CN. An official critical care societies collaborative statement: burnout syndrome in critical care health care professionals: a call for action. Am J Critical Care. 2016;25(4):368-376. doi:10.4037/ajcc2016133

11. Edmondson EK, Kumar AA, Smith SM. Creating a Culture of Wellness in Residency. Acad Med. 2018;93(7):966-968. doi:10.1097/ACM.0000000000002250

12. Lu DW, Dresden S, McCloskey C, Branzetti J, Gisondi MA. Impact of burnout on self-reported patient care among emergency physicians. West J Emerg Med. 2015;16(7):996-1001. doi:10.5811/ westjem.2015.9.27945

13. Sajjadi S, Norena M, Wong H, Dodek P. Moral distress and burnout in internal medicine residents. Can Med Educ J. 2017;8(1):e36-e43. doi:10.36834/cmej.36639

14. Watkins S, Ruskin KJ, Schwengel DA. Patient Safety and Physician Well-Being: impact of COVID-19. ASA Monitor. 2021;85(1):21. doi:10.1097/01.ASM.0000725848.61435.b5

15. Carayon P, Perry S. Human factors and ergonomics systems approach to the COVID-19 healthcare crisis. Int $J$ Quality Health Care. 2021;33(Supplement_1):1-3. doi:10.1093/intqhe/mzaa109

16. Baer TE, Feraco AM, Tuysuzoglu Sagalowsky S, Williams D, Litman HJ, Vinci RJ. Pediatric resident burnout and attitudes toward patients. Pediatrics. 2017;139(3):e20162163. doi:10.1542/peds.20162163

17. Knupp AM, Patterson ES, Ford JL, Zurmehly J, Patrick T. Associations among nurse fatigue, individual nurse factors, and aspects of the nursing practice environment. JONA. 2018;48 (12):642-648. doi:10.1097/NNA.0000000000000693

18. Cole A, Ali H, Ahmed A, Hamasha M, Jordan S. Identifying Patterns of Turnover Intention Among Alabama Frontline Nurses in Hospital Settings During the COVID-19 Pandemic. J Multidiscip Healthc. 2021;14:1783-1794. doi:10.2147/JMDH.S308397

19. Paiano M, Jaques AE, Nacamura PAB, Salci MA, Radovanovic CAT, Carreira L. Mental health of healthcare professionals in China during the new coronavirus pandemic: an integrative review. Rev Bras Enferm. 2020;73((Suppl 2)):e20200338. doi:10.1590/0034-71672020-0338

20. Sommerstein R, Fux CA, Vuichard-Gysin D, et al. Risk of SARS-CoV-2 transmission by aerosols, the rational use of masks, and protection of healthcare workers from COVID-19. Antimicrob Resist Infect Control. 2020;9(1):100. doi:10.1186/s13756-020-00763-0

21. Lai J, Ma S, Wang Y, et al. Factors associated with mental health outcomes among health care workers exposed to coronavirus disease 2019. JAMA Network Open. 2020;3(3):e203976. doi:10.1001/ jamanetworkopen.2020.3976

22. Thomas J, Harden A. Methods for the thematic synthesis of qualitative research in systematic reviews. BMC Med Res Methodol. 2008;8 (1):45. doi:10.1186/1471-2288-8-45

23. Page MJ, McKenzie JE, Bossuyt PM, et al. The PRISMA 2020 statement: an updated guideline for reporting systematic reviews. BMJ. 2021;372:n71. doi:10.1136/bmj.n71
24. Critical Appraisal Skills Programme. CASP qualitative research checklist; 2013. https://www.casp-uk.net/casp-tools-checklists. Accessed February 1, 2021.

25. Góes FGB, Silva A, Santos AS, et al. Challenges faced by pediatric nursing workers in the face of the COVID-19 pandemic. Rev Lat Am Enfermagem. 2020;28:e3367. doi:10.1590/1518-8345.4550.3367

26. Fawaz M, Samaha A. The psychosocial effects of being quarantined following exposure to COVID-19: a qualitative study of Lebanese health care workers. Int J Soc Psychiatry. 2020;66(6):560-565. doi:10.1177/0020764020932202

27. Arnetz JE, Goetz CM, Arnetz BB, Arble E. Nurse Reports of Stressful Situations during the COVID-19 Pandemic: qualitative Analysis of Survey Responses. Int J Environ Res Public Health. 2020;17(21):8126. doi:10.3390/ijerph17218126

28. Lee N, Lee H-J. South Korean Nurses' Experiences with Patient Care at a COVID-19-Designated Hospital: growth after the Frontline Battle against an Infectious Disease Pandemic. Int $J$ Environ Res Public Health. 2020;17(23):9015. doi:10.3390/ijerph17239015

29. George CE, Inbaraj LR, Rajukutty S, de Witte LP. Challenges, experience and coping of health professionals in delivering healthcare in an urban slum in India during the first 40 days of COVID-19 crisis: a mixed method study. BMJ Open. 2020;10(11):e042171. doi:10.1136/bmjopen-2020-042171

30. Galehdar N, Kamran A, Toulabi T, Heydari H. Exploring nurses' experiences of psychological distress during care of patients with COVID-19: a qualitative study. BMC Psychiatry. 2020;20(1):489. doi:10.1186/s12888-020-02898-1

31. Nyashanu M, Pfende F, Ekpenyong M. Exploring the challenges faced by frontline workers in health and social care amid the COVID-19 pandemic: experiences of frontline workers in the English Midlands region, UK. $J$ Interprof Care. 2020;34 (5):655-661. doi:10.1080/13561820.2020.1792425

32. Bennett P, Noble S, Johnston S, Jones D, Hunter R. COVID-19 confessions: a qualitative exploration of healthcare workers experiences of working with COVID-19. BMJ Open. 2020;10(12):e043949. doi:10.1136/bmjopen-2020-043949

33. Eftekhar AM, Naserbakht M, Bernstein C, Alazmani-Noodeh F, Hakimi H, Ranjbar H. Healthcare providers experience of working during the COVID-19 pandemic: a qualitative study. Am J Infect Control. 2021;49(5):547-554. doi:10.1016/j.ajic.2020.10.001

34. Liu Q, Luo D, Haase JE, et al. The experiences of health-care providers during the COVID-19 crisis in China: a qualitative study. Lancet Global Health. 2020;8(6):e790-e798. doi:10.1016/S2214109X(20)30204-7

35. Maglalang DD, Sorensen G, Hopcia K, et al. Job and family demands and burnout among healthcare workers: the moderating role of workplace flexibility. SSM Population Health. 2021;14:100802. doi:10.1016/j.ssmph.2021.100802

36. Torrente M, Sousa PAC, Sánchez-Ramos A, et al. To burn-out or not to burn-out: a cross-sectional study in healthcare professionals in Spain during COVID-19 pandemic. BMJ Open. 2021;11(2): e044945. doi:10.1136/bmjopen-2020-044945

37. Jalili M, Niroomand M, Hadavand F, Zeinali K, Fotouhi A. Burnout among healthcare professionals during COVID-19 pandemic: a cross-sectional study. Int Arch Occup Environ Health. 2021;94 (6):1345-1352. doi:10.1007/s00420-021-01695-x

38. Dzeng E, Wachter RM. Ethics in Conflict: moral Distress as a Root Cause of Burnout. J Gen Intern Med. 2020;35(2):409-411. doi:10.1007/s11606-019-05505-6 


\section{Publish your work in this journal}

The Journal of Multidisciplinary Healthcare is an international, peerreviewed open-access journal that aims to represent and publish research in healthcare areas delivered by practitioners of different disciplines. This includes studies and reviews conducted by multidisciplinary teams as well as research which evaluates the results or conduct of such teams or healthcare processes in general. The journal

covers a very wide range of areas and welcomes submissions from practitioners at all levels, from all over the world. The manuscript management system is completely online and includes a very quick and fair peer-review system. Visit http://www.dovepress.com/testimonials. php to read real quotes from published authors. 